\title{
THEFT PREVENTION WITH RAHAT AS AN EFFORT TO PROTECT PROPERTY IN PASAMAN, WEST SUMATERA, INDONESIA
}

\author{
Salma \\ UIN Imam Bonjol Padang \\ salma@uinib.ac.id \\ Jarudin \\ Sekolah Tinggi Keguruan Dan Ilmu Pendidikan PGRI \\ Gunung Pangilun Padang \\ jarudin@stkip-pgri-sumbar.ac.id
}

\begin{abstract}
This article aims to explore about rahat as an effort to protect property in Pasaman, West Sumatera, Indonesia. Stealing was a criminal act which threatened the perpetrator with severe punishment, imprisonment in Indonesia or hand-amputation in Islamic law. The punishment was not only to deter and punish the perpetrator but also to educate society not to make the same mistake. However, when the national and religious laws did not function efficiently, the people in Pasaman, West Sumatera, Indonesia protected their properties with rahat, the magical fence consisting of tayyibah (noble words) which prepared by the leader of Islamic traditional boarding school (pesantren). When a thief broke the fence, he may forget his initial intention to steal, feel being locked, or even sickened in
\end{abstract}


to an unrecoverable illness. Rahat and its effects were announced in public, delivered mouth to mouth, and obeyed by the community. As the result, the people were prevented from taking other people's possessions; the treasures of society were also well preserved. The type of the study was field research with a qualitative approach. The data was gathered by observation, indepth interviews, and documentation study. The analysis was done descriptively by data reduction, display, and verification (drawing conclusion).

Keywords: Islamic sharia, property, punishment, rahat, theft.

\section{A. Introduction}

Theft is reported in numerous media, either printed or electronic, every day. The media report the methods, patterns, and modus of the thieves which seem to be becoming more sophisticated and difficult to handle for the government. Theft is universally rejected in any religion and community. In Indonesia, regulation of theft, including the punishments, are recorded in Kitab Undang-undang Hukum Pidana (KUHP)Book of the Criminal Code, article 362 to 367. In article 365 part 4 , it is stated that theft with violence and with the result of death can be sentenced with the death penalty or life imprisonment (Alrasid, 2006). The aim of the punishment is commonly used to educate the society (Bahnasi, 1970). Theft happens so frequently in Indonesia that police, prosecutors and judges are kept busy to process the law for the perpetrators and sending them to jail. Some of them repeat the same crimes and take prisons as common place. Some groups of people try to find and use mystical methods to protect their own property. 
Badan Pusat Statistik (BPS) data states that from 20162018 period the number of crimes in Indonesia fluctuated. The crime rates in 2016 was 357.197 per 100.000 people and decreased to 336,652 per 100.000 in 2017 . The rate decreased again in 2018 to 294,281 per 100.000 . Crimes against property are classified into several types, such as ordinary theft (nonviolent), theft with violence or theft with sharp weapons. Data from BPS states that theft without using violence is the most common type of crime in terms of numbers every year. In 2016-2018 there were 317,825 thefts per 100,000 people without using violence in Indonesia (Badan Pusat Statistik, 2019). The case of theft in Indonesia is the type of crime with the most recidivists (https://megapolitan. kompas.com/ $\mathrm{read} / 2016 / 12 / 29 / 17470511 /$ ini.11.jenis. kejahatan.yang. menonjol. selama. 2016.) There were 11 types of cases that stood out the most in 2016 with theft being most common. A total of 11 cases were weighted theft and as many as 3,187 cases of ordinary theft as well as 719 cases of violent theft, and motor vehicle theft with 2,866 cases. Meanwhile, there were only 71 cases of murder. These facts show that Lombroso's theory is true (Lombroso \& Horton, 1968). According to him, the acts of murder and theft have different characters. Stealing is a habitual product that begins with the habit of taking objects of little value or value in the house/family. The habit then developed and shifted to the area outside the house with a larger nominal value. Finally, the habit of stealing will never stop because it has become an ingrained trait in the thief, even though he has been caught and punished many times. As for the act of murder, this is not a basic characteristic because killing is not something that is learned and habituated like 
theft. Therefore, many community groups handle theft cases that occur around them in their own ways.

On the other hand, Indonesia is a country with the most populous Muslim society. As Muslims, they have life guidance, Qur'an and sunnah. They are the sources to regulate aqidah (believe), 'ibadah (worship), mu'amalah (livelihood), akhlak (morals), and other life regulations. One of them forbids theft and prescribes severe punishment for the perpetrator. Theft (al-sariqah) is grouped into the hudud concept as one type of jarimah (Al-Mawardi, 2010), (al-Sarakhasi, 2012), and (alZuhaili, 1997). As a part of the hudud, the punishment then for the perpetrator is explained explicitly (qat'iy) in Qur'an and Sunna. One of them is in sura al-Maidah, 5: 38 stating that the punishment for theft is hand-amputation. In addition, in the sunna, there are a lot of hadiths which explain the minimum value of the stolen property for sentencing hand-amputation (Al-Jassas, 1988). The hadd al-sariqah is not practiced yet in Indonesia. Nonetheless, the laws of the State governing theft are sufficient to achieve the objectives of the punishment, among others, to prevent the perpetrator from repeating his actions and to educate the public not to commit the same act. The recitation, learning, and comprehension of the Qur'an which explains theft, at least helps explain why theft is wrong, so that every Muslim can prevent himself from committing the crime. However, there are those who still commit theft.

The condition makes certain groups of people feel that they need to protect their own property without relying on the state law and Islamic law (hudud). They try to find and use an alternative to protect their property as well as to prevent and handle the theft. One of them is using mystical methods 
in order to achieve the aim of punishing the thief; the thief becomes deterred and other people become afraid of stealing. Then, the property of society is protected. For example, Sugiantari conducted research about handling several theft cases of sacred objects in some areas in Bali; one of them is Plaga, Petang, Badung. The community dominantly referred to state laws; but the recovery of the sacred objects was urgent as the customs of society was affected by the theft. Therefore, in order to prevent the theft of sacred objects and to provide legal protection for the Pakraman village, the people conducted awig-awig Desa Pakraman ceremony, a religious ceremony or ritual (Sugiantari \& Julianti, 2016). Jamaa states that the people of Telaga Pange and Telaga Kodok villages believe that matakao may affect the physical effects to the thief stealing plants or cattle fenced with matakao. Matakao karimpu gives a psychological effect; the thief will find it difficult to find the way out of the farming area until the owner or someone else finally finds him. The pain felt by the thief will disappear as he gets the antidote, admits his crime, and repents before the owner (Jamaa, 2016). The society chooses to choose the mystical method in handling theft because it is believed to be more effective to handle stealing which is usually difficult to handle in the common way. Runturambi states that the belief system becomes a part in the sociocultural process successful to handle crimes, as in theft. Like theft with the famous method of hypnotizing creates its own difficulty to prevent self from such crime. On the other hand, the increase of hypnotizing in theft is related to social problem and ineffective law enforcement (Runturambi, 2014). From the weaknesses of law enforcement, people try to seek their own 
ways to protect their properties. Other than above mentioned sample societies, there is one area in West Sumatra, Indonesia practicing rahat, a mystical method to protect properties and prevent them from theft. The area is Pasaman, a part of Minangkabau's rantau (coastal area/overseas). The objective of this study is to reveal property maintenance (hifz al-mal) in Islamic law, theft in Islamic teachings, the meaning and the making of rahat, the location of rahat, the content and type of rahat, and the steps of use, the levels, effects, and abstinence of rahat and the recovery methods of the rahat effect.

In answering the research problems appropriately, primary and secondary data were used in this study. The primary data was obtained through in-depth interview with some key participants who settled down before going to the location such as rahat practitioners (the leaders of the pesantren, people who asks for rahat, leader of the clan, and local experts of Islamic law. The secondary data was obtained from literature related to the topic. The data was analyzed descriptively through reduction, display and verification.

\section{B. Property Maintenance (Hifz al-Mal) in Islamic Law}

All people need property to fulfill their life needs and make the life easier (al-Raisuni, 2002). Islamic teachings in Qur`an and Sunna guide people to get property in the proper ways as well as to spend them in the proper ways. In sura alJum'ah, 62: 10, God orders all Muslims to work hard collecting properties as the rahmah (bless) and gift from Him; fortune in life is guaranteed by property. In sura al-Baqarah, 2: 172, God reminds all people only to eat and spend the properties which are collected with good and proper ways. In the same sura 
verse 167 , God says that Muslims only consume halal and tayyib (good) properties. In a tradition of Prophet Muhammad (peace be upon him), the best work is to collect property by self-efforts, using one own hand. God (Allah) and Prophet Muhammad remind us not to follow Satan in collecting and spending property. There are a lot more verses of Qur'an and Sunna explaining and reminding every Muslim to stay within the border of halal (good and legal) whenever he is searching, gathering, developing, and spending property in fulfilling daily needs.

As property is important in God's view, it posts an aspect of Islamic teachings (sharia) that must be maintained. In the study of Islamic law, it is known as ad-daruriyat al-khamsah, the necessity to maintain religion (hifz al-din), soul (hifz al-nafs), mind (hifz al-'aql), offspring (hifz al-nasl), and property (hifz al-mal) (al-Raisuni, 2002). Therefore, in maintaining religion, God and Prophet state that the Muslims must hold firm their religion by performing all orders, like salah and zakat (sura alBaqarah, 2: 3), fasting (sura al-Baqarah, 2: 183), and rejecting all forbidden things, such as adultery (sura al-Isra', 17: 31) and stealing (sura al-Maidah, 5: 38). Even when a Muslim converts to another religion, sharia has regulated a punishment as a way to prevent the religion (sura al-Baqarah, 2: 217). In nourishing the soul, following sharia, everyone has to save himself by not doing things threatening his safety and not keeping away from other's soul, since it is threatened with severe punishment (alBaqarah, 2: 178). In protecting the human mind, sharia obliges the Muslim to maintain things, especially in the consumption of foods or drinks, in order to keep the mind adjusted. In Islamic teachings, mind takes a very important role as the standard 
or measurement to make everyone to be responsible for all his acts. At this step, he already becomes a mukallaf individual (baligh/mature and mindful) whom is already able to practice religious obligations. Therefore, God and Prophet Muhammad (peace be upon him) provide punishment for those who try to ruin the mind through consuming the haram (forbidden) foods and drinks, like khamr (alcohol) and other drugs (sura al-Maidah, 5: 90). Then, in preserving offspring, God decides that eligible Muslims should be married in order to procreate properly (sura an-Nisa', 4: 3); a severe punishment awaits those who fulfill biological needs improperly, like fornication or adultery (sura an-Nur, 24: 2), homosexuality (sura al-A'raf, 7: 80), and bestiality. Similarly, God and Prophet guarantee property maintenance by stating rules that everyone will earn property properly and halal, for then to spend them also in the proper ways (sura an-Nahl, 16: 114). Islam threatens anybody who takes other's property improperly with a severe punishment; for instance, God orders to amputate the hand and foot of anybody who steals or robs in the zalim (unjust) ways.

\section{Theft in Islamic teachings}

Theft is known as al-sariqah in Islamic teachings. It is one type of hudud (the punishments which have been regulated in Qur'an and Sunna). Either in language or terminology, theft is referred in the same ways, taking other's property without his/her knowing (al-Kubaisi, 2001). As a part of the hudud, the punishment for the thief is stated in the Qur'an and Sunna, some of them are in sura al-Maidah, 5: 33 and 38, amputating a hand or a foot. The more detailed explanation about the punishment is also found in a lot of 
hadith of Prophet Muhammad. The punishment is very severe and the judge needs to be very careful in deciding the law of hand-amputation for a thief. He needs to conduct an in-depth analysis about the requirements in hadd al-sariqah in order to be able to set the sentence.

Theoretically, there are at least some requirements that must be fulfilled in a theft case to sentence hand amputation: the requirements that must be laid upon the thief himself and the requirements that must be laid upon the stolen property. The first group considers that the thief must be a Muslim, baligh (mature), mindful, free person, and committed stealing without being forced by the urgent condition/need. Meanwhile, the second group says, firstly, the property completely belongs to the victim without affiliation to another party (al-Shirazi, 2005). Secondly, the property was secured (Qudamah, 2012). The safety standard refers to the tradition or custom of the society, such as keeping in a cupboard or safety box. Thirdly, the property fulfills the nisab (the minimum amount/value). The nisab (al-Hanafiy, 1995) of stolen property has been stated in many hadith of Prophet Muhammad. Some of the hadith explains that the nisab is $1 / 3$ gold dinar or 3 silver dirhams. There are also some hadith explaining that the nisab is 1 gold dinar or 10 silver dirham (al-Hanafiy, 1995). Conversing to the current value of today gold, 1 gold dinar equals to about 4.45 grams of gold or about 2.5 to 3 million rupiahs. Fourthly, the property stolen was considered valuable.

In a state where the majority of residents are Muslims, Indonesia does not perform hadd al-sariqah rules in the legal system. Indonesia follows the regulations of the Kitab 
Undang-undang Hukum Pidana. However, Aceh, a province with a special status, has Qanun Aceh (Aceh Act) Number 6 Year 2014 about Jinayat Laws; hadd al-sariqah is not regulated with hand-amputation there, but other hudud types like hadd al-zina are regulated in the Qanun. A researcher said that the Qanun in Aceh is the more moderate hudud concept (Mabrur et al., 2017). In other Islamic countries, hadd al-sariqah has been regulated in their legal system and has been performed to sentence thieves. Like a criminal in Sana'a, Yemen, he was sentenced with the crossed hand-amputation by the Special Criminal Court of Sana'a on 15 September 2013; his right hand and left foot were amputated. The sentence was performed after the judge had referred to the elements fulfilled in the theft case (Chottiner, 2013).

\section{The Existence of The Rahat in Rantau Pasaman}

\section{The demography of Rantau Pasaman}

Administratively, Pasaman, West Sumatera, consists of two kabupatens (districts) Pasaman and Pasaman Barat. Both kabupatens were under a single government. In 2003, they were expanded into two kabupaten regarding the Act Number 38 Year 2003 (Undang-undang Nomor 38 Tahun 2003), because they covered areas too wide to rule in one administrative government of kabupaten. The people residing in the area are commonly from three ethnicities Minangkabau (approximately 50\%), Mandailing (approximately 35\%), and Javanese (approximately 15\%). They have different customs, cultures, and languages (Minang, Mandailing, and Javanese), but they commonly understand 
Minangkabau and communicate inter-culturally through the Indonesian language (Awaluddin, 2015). The coming of the Mandailing people to Pasaman was caused by the territorial expansion of the Batak kingdom which stood next to Pasaman territory. The Javanese came to Pasaman through the transimigration program in 1950s, even though approximately 1710 predecessors were already carried to Pasaman by the Dutch colonialization since 1935 as plantation workers (Undri, 2009).

Geographically, Kabupaten Pasaman lies between $0.55^{\circ}$ NL- $0.06^{\circ}$ SL and 99.45은 $-100.21^{\circ}$ EL. The height is of 50-2.912 meters above sea level. Kabupaten Pasaman is one of the special kabupaten in Indonesia since it is passes through the equator. It consists of 12 kecamatan (sub district), 32 nagari (village), and 309 jorong. Meanwhile, Kabupaten Pasaman Barat lies between

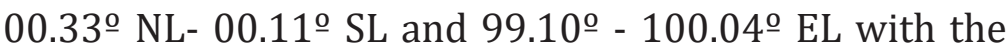
height of 0 to 913 meters above sea level. Kabupaten Pasaman Barat consists of 11 kecamatan, 19 nagari, and 202 jorong. The population is about 955.697 (in 2015). The religious majority are Muslims, which can be seen from the spread of mosques and mushallas across the region. In 2015, there were 434 mosques, 481 langgar, and 215 mushalla noted in Pasaman. The inter-ethnic social relation is considered harmonious and peaceful (Pemerintah Daerah Pasaman, 2016). This is in line with the vision proclaimed by the Kepala Daerah (the district leader) of Pasaman "membangun Pasaman di atas tadah agama, untuk kesejahteraan umat dunia dan akhirat." (Build Pasaman on the religious grounds, for the welfare 
of the people in the life and the afterlife) (Taufiq, 2012). The local government also runs a program preparing and training $76 d a^{\prime} i$ (Islamic preachers) for the nagaris to fulfil their roles giving light to society about Islam and social life. In addition, there are a lot of pesantrens (Islamic boarding schools), the traditional and modern, in several parts of Pasaman.

Intambo (Minangkabau's oral folktale), before Dutch colonialism ruled the western part of Sumatra's beaches, nagaris in Pasaman were under the rule of four raja adat (the king of customs) which was the sapiahbalahan (sister) kingdom of the Minangkabau kingdom centered in Pagaruyung. The four kings are Yang Dipertuan Padang Nunang with the center of the government in Rao, Tuanku Rajo Sontang in Cubadak, Tuanku Rajo Bosa Sundatar in Lubuk Sikaping, and Tuanku Bagindo Kali in Kumpulan (Taufiq, 2012). Therefore, Pasaman from the perspective of the Minangkabau kingdom is the rantau area, not a part of the Luhak Nan Tigo (Tanah Datar, Agam, and Lima Puluh Kota), the original areas of Minangkabau (Naim, 2013). There are many national heroes as well as the Islamic leaders (ulama) born in this region and who fought in this region, like Tuanku Imam Bonjol and Tuanku Rao.

\section{The Meaning and the Making of Rahat}

Some of the Pasaman people that resided in Melayu Sontang village say that rahat comes from Mandailing language meaning pagar diri (literally, self-fence, or self-protection) (Handayani, 2018). For instance, people 
say marahat dekobuni means the farm is fenced with a 'creature' that protects the area. The fence being referred to is not a literal fence made from wood, plant, or iron, but an unseen and metaphorical fence that resembles an actual fence. The Pasaman people in Simpang Ampek call rahat with uduah (Yulisa Marhan, 2018). The word is found in Kamus Besar Bahasa Indonesia meaning medical herbs used as a repellent (Departemen Pendidikan Nasional, 2008). The people of Muaro Kiawai Pasaman call rahat as uduah balega, because uduah can make a thief confused and cause him to circle around the target area for one week (Busmel, 2018). The people of Batang Saman and Paraman call rahat with kaua. They say that the word comes from the Arabic qaul meaning a series of words, because the kaua contains a roll of paper written with a mantra for fencing the property (Darmansyah, 2018). Some people in the area also call rahat as baubek (Zuarman, 2018), meaning that the area, farm, store, shop, or river has been treated with certain medication of a specific potion for the fence. It cannot be seen but has a bad effect to people intending to steal it. Some Pasaman people in Lubuak Landua call rahat by larangan (Mustafa Kamal, 2018), meaning certain areas forbidden by society to take something from it, to fish, or to do business within the area.

Larangan usually refers to the fish in a river which are targeted for orphans, the poor, or mosques. Rahat was given in order to prevent people from taking fish until the rahat time ends. Even though rahat appears in various terms but with the same substance, some of the people 
take uduah to have the most frightful effect. They think the term uduah more reflects the intention/willingness of the owner to harm the person who steals his property (A'lemi, 2018). It differs from rahat whose meaning is understood more as the effort to fence oneself or property from stealing. As the mystical fence, rahat is only created by the people considered the elders in religion (ulama). They are considered to have reached the level of sufi in the Tasauf in the eyes of the Pasaman people. Therefore, there are only a few of them, but they are not difficult to find. They live and work as the leaders of the Islamic boarding colleges, pesantrens, or pondok tarikat, who still keep the suluk tradition. To the researchers, they were very open for discussion and explanation about the origin of rahat.

\section{The Location of Rahat}

There are two locations of property fenced with rahat in Pasaman, the location of the personal property and the location of the public property. Some of the locations of the personal property are fishing pools and farms, and either orange, rubber, or palm oil farms. There are also the locations related with business, like stores, shops, minimarkets, or rice mills (Syahrijal, 2018). Among them, the farms, especially the orange and palm oil farms, are the most common areas protected with rahat. On the other hand, the location of public property protected with rahat is usually rivers flowing across nagari whose fish belong to the society; however, by the initiative of the leader, the fish are given rahat in order to save them 
for orphans and the poor in the nagari or to build or fix the mosque (Alin Tagak, 2018). In the research, there are several river streams with rahat, like the ones in Sontang, Muaro Kiawai, Limpato, Sungai Aur, and Lubuak Landua. The fish in the area are easily called by spreading foods, like bran, bread, and rice. The fish in Lubuak Landua are generally garing fish (mahseer fish). They look very benign and big; each of them is approximately 5 to 10 kilograms. This is because the rahat has been in place for a very long time and has not been given the antidote after the death of Buya Lubuak Landua, the one who gave the first rahat.

\section{The Content and Type of Rahat, and the Steps of Use}

Rahat is in the form of a collection of the mystical objects consisting of various kinds of objects. Generally, the content of rahat is just the same; some may be different in accordance to the knowledge of the people who gives the rahat, the practitioner. Every rahat practitioner explains it in the same way that the main content of rahat is the Arabic letters, either composed into the properties of God (especially the 20 properties) (Rahadian, 2004) or the fraction of the Arabic letters of the God's properties (Lasyadid, 2018).The supporting container of the rahat is a black tin, which is commonly found in the market; a part of animal's body, like a tiger's mustache, which is very difficult to find but usually kept by the rahat practitioner; antelope skin; paper; kaffir lime; jeruk pasir; jeruk sundai (citrus aurantifolia); needles; threecolors of yarn: red, black, and white (Handayani, 2018); 
frankincense; dasun (onion with a single clover); inggu (the tree sap with black color and sharp and stinging smell); coconut shells; white cloths; bran; empty paddies; and rice. When someone comes asking for a rahat, the practitioner asks him to collect the materials of the rahat required, except the ones which are difficult to find. In this case, the practitioner will provide the object.

The process of preparing and using the rahat are done by the practitioner and the people asking for the rahat. The practitioner needs time about three weeks to prepare the rahat. The first step is preparing the supporting materials needed because not all of them can be used for a certain rahat. The next step is fasting for three days (it will better to fast in consecutive days). The third step is doing the night salah for three times on Friday nights. After salah, the practitioner is praying while the rahat materials are arranged on the right side of his prostrations pot. The full prayed rahat is then handed to the one who asks, the customer (Mustafa Kamal, 2018). Then, he continues with the process of setting the rahat by putting or planting it in a specific place which is decided, like in the middle of a farm, or in its each corner. During the process, the asker is obliged to recite as many as possible sura al-Fatihah and salawat to the Prophet Muhammad (Darmansyah, 2018).

\section{The Levels, Effects, and Abstinence of Rahat}

The rahat practitioners say that there are at least three levels of rahat with the different contents and effects on the thieves. The first level rahat functions to 
change or even dismiss the willingness to steal whenever he is nearby and has seen his target (Anshori, 2012). The second level rahat functions to lock or trap the thief on the spot of crime. The thief feels being locked, loses his way, and walks circularly within the location until the owner finds him and shocks him in order to stop the feeling. In this case, only the owner of the property can wake up the thief even though other people have been gathered in the location to try to wake him up. The third level rahat functions to hurt the thief. This is the highest level of the rahats; not all practitioners are willing to give rahat of this level considering the danger threatening the criminal. They already believe that the punishment from God, as written in the rahat, will occur and they cannot stand to see the effect on the criminal. For instance, the giver wrote the property of God'Aliman (The Most AllKnowing), then God all-knows the intentionand act of the thief and punishes him severely for the bad conduct (stealing). The recovery from the third level rahat is very difficult and almost impossible, especially when the practitioner dies or moves to a distant place.

The Pasaman society also believes that rahat also comes with certain abstinence that cancels the effect to thieves. First, the rahat prepared is not allowed to be step over before being set in the location, farm, shop, or river. When it is violated, the effect will disappear immediately. Second, the criminal has the blood line with the asker (family), like sibling or uncle. In that condition, the effect of the rahat dismisses either on the thief or on other nonrelatives. Third, the thief takes off all his clothes before 
entering the target location. When he does this, the effect of the rahat will not affect him but my still work to other persons. Fourth, the thief is not a Muslim; the rahat does not affect non-Muslim since he does not even believe in Allah as the only God that can punish man for bad deeds, including stealing. Fifth, only for the river protected with rahat, the public is not allowed to take the fish before the practitioner. When they disobey, the fish, which were previously numerous, will mysteriously disappear. As it occurs, that indicates that someone in the society has broken the abstinence of the rahat (Tuanku Bosa, 2018).

\section{The Recovery Methods of the Rahat Effect}

There are two methods for recovering from the rahat effects in Pasaman, recovering the criminal and recovering the object protected with rahat by neutralizing the effect in order to make it able to be bought, owned, taken, and consumed by other people. As the effect of rahat on the thief depends on the level, the curing process is also different. The first and second level rahat can be cured without the antidote. Recovery is done by the owner of the property only by touching or patting the shoulder of the thief. The act must be followed by the thief admitting his wrong intention to the owner, apologizing, and doing two raka'as of salah as the proof of taubah (repentance) to God for his bad act. The salah is called as shalah ojat (hajat salah) by the Pasaman people. On the other hand, the third level rahat is very difficult to cure because this type harms the thief, especially his internal organs. The recovery can be done by admitting his act to the owner 
and seeking the practitioner because only he can cure the effect. The recovery is done by baruruah. Its ingredients usually consist of water, salt, young coconut water, and jariangau (acorus calamus). All ingredients are boiled and put into a container then a prayer is recited by the rahat practitioner.The thief drinks it slowly and then vomits all the contents of his stomach. By then, it is believed that he is already free from the effect of the rahat. It did happen to three santris (Islamic traditional boarding school students) who took fish from a river which was protected with rahat (Muzakkir, 2018). However, the perpetrator rarely admits his act since he is too ashamed to face the owner. He then suffers from stomachaches, turns thinner but with a swallowing stomach, and dies within a month. By the characteristics, the people believe that he had stolen something from a property fenced with rahat.

The methods of neutralizing rahat to the personal and public properties are done differently in each area of Pasaman. For example, in Batang Saman and Limpato, people neutralize the effect of rahat by burning frankincense and smoking the property while reciting $d u^{\prime} a$ (prayer) taught by the practitioner. The people in these areas usually give rahat to orange and palm oil farms. When the buyer wants to buy the oranges by picking them himself, he must be accompanied by the owner and must be forbidden from eating the oranges before being neutralized by the owner (Yunita, 2018). The people of Sontang neutralize the effect by spreading yellow sticky rice around the property protected with rahat. Then, the elders of Muaro Kiawai neutralize fish by 
catching, cooking, and eating some of them first and then let other people in the community catch the rest.

\section{E. Applying Rahat in Islamic Sharia}

Based on the description above, it is known that some Pasaman people use rahat as an effort to protect their property. The meaning of rahat, for them, is more to protect their property than to harm the thieves. The location of rahat are at the personal property and the location of the public property such as fishing pools and farms, and either orange, rubber, or palm oil farms. Rahat is in the form of a collection of the mystical objects consisting of various kinds of objects. There are at least three levels of rahat with the different contents and effects on the thieves. There are two methods for recovering from the rahat effects in Pasaman, recovering the criminal and recovering the object protected with rahat by neutralizing the effect in order to make it able to be bought, owned, taken, and consumed by other people. As a means of protecting property, ordinary rahat is provided by pious people who are known for their religious understanding and practice. Something that is very synonymous with the Minangkabau community.

The Minangkabau kingdom succeeded in running Islam law (Shari'a) and the cosmology of Hinduism (adat). These two basics are known as adat basandi syarak, syarak basandi kitabullah, syarak mangato, adat mamakai. Although there are fluctuations in Islamic relations with Minangkabau culture, especially in 19th century. Abdullah and recently Chuzaifah studied acculturation between adat and Islamic tenets (Abdullah, 1972 \& Chuzaifah, 2002). The results showed that 
the traditions of Muslim community in Pasaman still hold certain beliefs outside of the Islamic value. The tradition mirrors to the tradition of calling rain (dhammong) in Madura (Hefni, 2008), bathing forty times or cebor opatoh (Syukur \& Qodim, 2017) in Garut and tradition of Samin community in East Java (Oktafia \& Mawardi, 2017) but has some major differences comparing with begalan in Banyumas (Hidayat, 2014). The rahat practitioners have some similarities with pananyaan in Tasikmalaya (Musadad, 2016) and lawang/ kuncen in Garut (Syukur \& Qodim, 2017). Muslim community in Pasaman think that the rahat has a close relationship with religious as well as mystical aspects. In light, the mystical traditions contained in religions are similarly found in physics modern theory (Umar, 2016).

Rahat is still exist. As the matter of a fact, the people believe that the tradition orange garden has been determined by God. On the other hand, there are other factors which influenced the sustenance. Mohsen says that the sacred and profane dualism are included in the existence of spirits and others demand arise from themselves to keep trying the provision unobstructed even though the way is not regulated in the Shari'a (Abdulnaser Sultan Mohsen, 2014). The existence of offerings in rahat rituals, chanting and sometimes interspersed with recitations of certain verses of the Qur'an indicate that the religious practices in Pasaman community are recognized as the result of the syncretism in Javanese society (Geerts, 1960) although Islam is the dominant force in rites and public trust (Salim, 2013).

One of the main factors describing Islam in the society is the acculturation of Islamic values with local wisdoms. The 
acculturation is commonly in esoteric way. This paper presents an overview of the acculturation between Islam and the local mystic tradition represented in the ritual of rahat. This study is necessary to conduct because the universality of Islam requires operational elaboration, the existence is more striking and felt. Furthermore, the universality of Islam will not be effective if it is separated from the values of local wisdom. Therefore, there is a basic concept of self in addition to humans whom people believe is in the realm of both animals, soil, trees and others,while for the rahat practicing, self-concept exists only in God, who they worship, while the nature represented by chisels serves as an intermediary (wasilah) between humans and God (Karomi, 2013 \& Maarif, 2015).

In the end, rahat which is interpreted as a fence without the intention of harming others, especially the thieves, returns to the basic factors of how the Minangkabau Muslim community, especially the Pasaman people, understand Islam as their religion. Islamic law teaches that everyone should protect the property rights that God has given him. Safeguarding this properly obtained property is an obligation. Although the way of doing it is outside the provisions set by the State. Therefore, rahat and all its mechanisms cannot be called an act of associating Allah with something else (shirk). It can be concluded that the meaning of rahat is not from the person who perceives it, but the meaning comes from the people who do it and it becomes the cultural wealth of the Muslim Minangkabau community. 


\section{F. Conclusion}

The practice of the rahat to protect property and prevent theft does occur in Pasaman. The people there generally comprehend that rahat is the mystical method, because the effects are feared. Therefore, one who asks for a rahat in Pasaman realizes that it is very important to inform others that his property has been protected with a rahat. The rahat has full of meaning, the making is related to worship (ibadah), one of the contents is the one of the God's properties, the highest level can cause death, although the other two levels can be cured but still embarrassing.

In Islamic Sharia, rahat which is interpreted as a fence without the intention of harming others, especially the thieves, returns to the basic factors of how the Minangkabau Muslim community, especially the Pasaman people, understand Islam as their religion. Islamic law teaches that everyone should protect the property rights that God has given him. Safeguarding this properly obtained property is an obligation. Although the way of doing it is outside the provisions set by the State. Therefore, rahat and all its mechanisms cannot be called an act of associating Allah with something else (shirk). It can be concluded that the meaning of rahat is not from the person who perceives it, but the meaning comes from the people who do it and it becomes the cultural wealth of the Muslim Minangkabau community.

Based on the results of the research above, it can be recommended to the community to avoid using rahat as much as possible because of the extraordinary effects that can occur on thieves. When bad results occur, the victim cannot prove who the culprit is. This will only lead to prejudice in the community. 


\section{REFERENCES}

Abdullah, T. (1972). Modernization in Minangkabau World, West Sumatra Early Decades of 20th, in Claire Hold (ed.), Culture and Politic in Indonesia. Ithaca Cornel Univ. Press.

Abdulnaser Sultan Mohsen. (2014). The Ontological Concept of Sacred and Profane in Islam (analytic study). Global Journal Al-Thaqafah, 4(1), 117-126. https://doi. org/10.7187/GJAT602014.04.01

al-Hanafiy, I. al-Humam. (1995). Sharh Fath al-Qadir (Vol. 5). Dar al-Kutub al-Ilmiyah.

al-Raisuni, A. (2002). Nazarriyat al-Maqasid 'inda al-Imam alSyatibi. Muassasah al-Risalah.

al-Zuhaili, W. (1997). Al-Fiqh al-Islami wa Adillatuhu: Vol. VII. Dar al-Fikr.

A'lemi. (2018). People who has a plantation which is fenced by rahat [Personal communication].

Alin Tagak. (2018). Practitioner or maker of the rahat [Personal communication].

al-Jassas. (1988). Tafsir Ayat Ahkam. Dar al-Fikr.

al-Kubaisi. (2001). Ahkam al-Sariqah. Mathba'ah al-Irsyad.

al-Mawardi. (2010). Al-Ahkam al-Sulthaniyah. Dar al-Fikr.

Alrasid, H. (2006). Himpunan Peraturan Perundang-undangan Republik Indonesia. Ichtiar Baru Van Hoeve.

al-Sarakhasi. (2012). Kitab al-Mabsuth Vol. 9. Mathba'ah alSa'adah.

al-Shirazi. (2005). Al-Muhadzdzab Vol II. Dar al-Fikr. 
Anshori, M. A. (2012). Mencari Titik Temu Agama-Agama: Upaya Mengatasi Konflik Keagamaan. Analisis, 12(2).

Awaluddin, N. (Ed.). (2015). Kerajaan Minangkabau dalam Pusaran Badai Zaman. Pemerintah Daerah Sumatera Barat Dinas Pendidikan dan Kebudayaan UPTD Museum Adityawarman.

Badan Pusat Statistik. (2019). Statistik Kriminal 2019. Badan Pusat Statistik.

Bahnasi, A. fathi. (1970). Al-'Uqubah fi al-Fiqh al-Islami. Dar al-Fikr.

Busmel. (2018). People who fenced a river by rahat [Personal communication].

Chottiner, L. (2013). Amputation case paints Islam in bad light, but Jews can relate. Jewish Cronicle, 57(21).

Chuzaifah, Y. (2002). Dekonstruksi Makna Kuasa dalam Matriarchy. Studia Islamika, 9(2), Article 2. https://doi. org/10.15408/sdi.v9i2.670

Darmansyah. (2018). Local Religious Leader [Personal communication].

Departemen Pendidikan Nasional. (2008). Kamus Besar bahasa Indonesia (8th ed.). Gramedia.

Geerts, C. (1960). The Religion of Java. The University of Chicago Press.

Handayani. (2018). Practitioner or maker of the rahat [Personal communication].

Hefni, M. (2008). “Bernegosiasi” Dengan Tuhan Melalui Ritual Dhâmmong (Studi atas Tradisi Dhâmmong sebagai Ritual Permohonan Hujan di Madura). Karsa, 8(1), 8. 
Hidayat, S. (2014). Konsep Keluarga Sakinah Dalam Tradisi Begalan. Al-Ahwal, 7(1), 12.

Jamaa, L. (2016). Matakao sebagai Upaya Preventif dan Represif terhadap Tindak Pencurian di Pulau Ambon dalam Perspektif Hukum Islam. Al-Ihkam: Jurnal Hukum Dan Pranata Sosial.

Karomi, K. (2013). Tuhan dalam Mistik Islam Kejawen (Kajian atas Pemikiran Raden Ngabehi Ranggawarsita). Kalimah: Jurnal Studi Agama Dan Pemikiran Islam, 11(2), 287-304. https://doi.org/10.21111/klm.v11i2.97

Lasyadid, L. (2018). Practitioner or maker of the rahat [Personal communication].

Lombroso, C., \& Horton, H. P. (1968). Crime Its Causes and Remedies. Patterson Smith.

Maarif, S. (2015). Being a Muslim in Animistic Ways. AlJami'ah: Journal of Islamic Studies, 52(1), 149. https:// doi.org/10.14421/ajis.2014.521.149-174

Mabrur, A., Muhammad, R. A., \& Din, M. (2017). Konsepsi Pidana Hudud dalam Qanun Jinayat Aceh-Indonesia dan Brunei Darussalam. Kanun Jurnal Ilmu Hukum, 19(1), 19-44.

Musadad, A. N. (2016). Persinggungan Islam dan Tradisi Mistik Lokal: Studi Kasus Pananyaan dan Ahli Hikmah di Masyarakat Tasikmalaya. Indonesian Journal of Islamic Literature and Muslim Society, 1(1), 47. https://doi. org/10.22515/islimus.v1i1.77

Mustafa Kamal. (2018). Practitioner or maker of the rahat [Personal communication]. 
Muzakkir. (2018). Local Religious Leader [Personal communication].

Naim, M. (2013). Merantau: Pola Migrasi Suku Minangkabau. Rajawali Press.

Oktafia, R., \& Mawardi, I. (2017). Islamic Values in the Traditon of samin community in east Java. QIJIS: Qudus International of Islamic Studies, 5(1), 18.

Pemerintah Daerah Pasaman. (2016). Pasaman dalam Angka (Pasaman in Figure). Pemda Pasaman.

Qudamah, I. (2012). Al-Mughniy: Vol. IX. Dar al-Fikr.

Rahadian, H. F. (2004). Asmaul Husna dan Dua Puluh Sifat Allah. Mizan.

Runturambi, A. J. S. (2014). Dukungan Sistem Kepercayaan Dalam Kejahatan. Antropologi Indonesia. https://doi. org/10.7454/ai.v0i72.3480

Salim, A. (2013). Javanese religion, Islam or syncretism: Comparing Woodward's Islam in Java and Beatty's Varieties of Javanese Religion. Indonesian Journal of Islam and Muslim Societies, 3(2), 223. https://doi. org/10.18326/ijims.v3i2.223-266

Sugiantari, A.A.P.W., \& Julianti, L. (2016). Peranan AwigAwig Desa Pakraman dalam Mencegah Tindak Pidana Pencurian Benda Sakral di Desa Pelaga Kecamatan Petang Kabupaten Badung. Inovasi Ipteks Perguruan Tinggi Untuk Meningkatkan Kesejahteraan Masyarakat, 901.

Syahrijal. (2018). People who has a plantation which is fenced by rahat [Personal communication].

Syukur, A., \& Qodim, H. (2017). Islam, Tradisi Lokal, dan Konservasi Alam: Studi Kasus di Kampung Dukuh 
Kabupaten Garut. KALAM, 10(1), 141. https://doi. org/10.24042/klm.v10i1.339

Taufiq, S. M. (2012). Direktori Minangkabau 2012. Badan Pekerja Pucuak Adat Alam Minangkabau (BP-PAAM), Istano Silinduang Bulan Pagaruyuang.

Tuanku Bosa. (2018). The Great Leader of the Clans [Personal communication].

Umar, M. (2016). Konvergensi Agama Dan Sains Dalam Melacak Basis Ontologi Semesta: Tinjauan Hermeneutika Hadis Penciptaan. Jurnal Theologia, 27(1), 173-212. https:// doi.org/10.21580/teo.2016.27.1.925

Undri, U. (2009). Orang pasaman: Menelusuri sejarah masyarakat di rantau minangkabau. Lembaga Kajian Gerakan Padri.

Yulisa Marhan. (2018). Leader of an Islamic Boarding School [Personal communication].

Yunita. (2018). People who has a plantation which is fenced by rahat [Personal communication].

Zuarman. (2018). People who has a plantation which is fenced by rahat [Personal communication]. 